\title{
Examination of the Role of Business Ethics with Google Trends
}

http://doi.org/10.21272/bel.3(3).25-38.2019

\section{Lívia Benita Kiss}

$\mathrm{PhD}$ Student, PhD School of Management Sciences and Business Administration, Pannon University, Hungary

\begin{abstract}
Ethics has existed in religion and philosophy for thousands of years and has been applied to business activities in the same way ethical values and norms have been applied to everyday life. This article summarizes the arguments and counterarguments within the scientific discussion on the study of business ethics as the form of applied ethics, which studies morals, ethical principles and problems in the business environment. The main goal of the study is to analyze business ethics from the point of view of integration of general morals and ethical norms to business, a combination of key signs of the right (good) or wrong behavior while doing business, determined on the basis of expected behavior approved by the society. The study of the role of business ethics in the corporate sector of the economy allowed to determine the most general principles of business ethics, namely awareness, caring, compliance, consideration, fairness, honesty, implementation, integrity, integration, loyalty, responsibility, and trustworthiness. The methodological basis of the research is analytical, statistical and comparative methods based on the use of Google Trends. In general, in Google Books, the use of the term business ethics shows an exponential trend. The findings show that the highest search frequency of business ethics is in the "all" category, after that in the "business and industry" category, then in the "science" category, finally in the "law and government" category. On average, the highest interest frequency was in 2004 in all examined categories. The author has proved that a third-degree polynomial downward trend can be fitted to each time series. The analysis of this concept on a geographical basis showed that the interest frequency of the principles of business ethics was most significant in South and Central East Africa, in South and Southeast Asia, over and above in the Caribbean.
\end{abstract}

Keywords: business ethics, principles of business ethics, Google Trends, Google Books Ngram Viewer, time series analysis.

JEL Classification: C22, C88, D21, K22, K23, M14.

Cite as: Kiss, L.B. (2019). Examination of the Role of Business Ethics with Google Trends. Business Ethics and Leadership, 3(3), 25-38. http://doi.org/10.21272/bel.3(3).25-38.2019.

(C) The Author, 2019. This article is published with open access at Sumy State University.

\section{Introduction and Literature Review}

Ethics is the subject that examines the personal moral standards of the society (Velasquez, 2002). It answers the question of how these standards can be applied in life (Cheney et al., 2010). But what are these moral standards? According to Velasquez's opinion, moral standards are standards that deal with issues that have serious consequences, consequences that could be associated with feelings of shame and fear. Behind these standards stands a good reason, they are not based on authority, and they are not reduced to a level of selfinterest, nor can they be accused of partiality (Cheney et al., 2010).

The part of the social ethics being the business ethics. It has always been affected by the ethics of the era. People, particularly leaders of the world at dissimilar times of the world, they do not see morality and ethics which was obviously unethical to the succeeding period.

In recent years the term, business ethics has risen up the agenda of business as professionals are required to demonstrate the highest ethical standards. These are integral to being a professional. As well as being required to uphold their code of ethics, professional working in business is often involved in developing, defining and enforcing ethical values. As more and more companies adopt codes of ethics to guide employee behavior, the new challenge is to embed these values (Cohen, 2008).

The history of business ethics is tainted by and throughout the history of slavery history, history of colonialism and later by the cold war. The present discussion of business ethics is the ethical discussion of post-colonialism and post-world wars. The need for business ethics in the present era had begun gaining 
Business Ethics and Leadership, Volume 3, Issue 3, 2019

ISSN (online) - 2520-6311; ISSN (print) - 2520-6761

notice since the 1970s. In the past, firms started highlighting their ethical stature since the late 1980s and early 1990s, as the world witnessed grave economic and natural disasters caused by unethical business practices (Salehi et al., 2012).

In the 1960s the global interest in business ethics turned to causes. Most of these relate to macro or societal issues. Therefore, this period of time focused on macro/normative issues and even a much larger emphasis on macro/descriptive issues (Ferrell, Fraedrich, and Ferrell, 2008: 12). Business ethics as an academic field emerged in the 1970s, with a few business ethics courses being taught (De George, 2007). A lot of philosophers entered the business field with, e.g., the textbook contributions of Beauchamp and Bowie (1997), Ethical Theory and Business, Donaldson and Werhane (1999), Ethical Issues in Business: A Philosophical Perspective. Other early textbooks by philosophers emerged, including Richard De George (1982) and Manual Vasquez (2002). Most of the books listed focused on business ethics from macro/normative perspective and moral philosophy and however micro issues were also examined.

Why do we need ethics in business? The following list is from (https://businessjargons.com/businessethics.html):

Building strong relationships with customers and clients.

Consumer satisfaction.

Creating goodwill.

Gain confidence of customers.

Healthy competition.

Safeguarding consumer's rights.

Stop business malpractices.

Survival and growth of business.

The set of these principles and practices, that determine in the business organization the acceptable and appropriate behavior. It guides in taking everyday business decisions the managers and other executives. It stresses the stakeholders, such as employees, consumers, government, society, investors, shareholders on the impact of the business decision. From there we get to a first definition of the term.

\section{Definitions of business ethics}

A preliminary circumscription of business ethics is based on the fact that there should be a set of moral rules that govern how business decisions are made, how businesses operate and how people are treated. In business, there are many different people you have to account for such as customers or shareholders. Determining what to do when an ethical dilemma arises among these different interests can be extremely tricky. The business ethics are complex and multi-faceted. Some business ethics are imposed by law (https://www.yourdictionary.com/business-ethics).

The definition of ethics in business based on the principle of equal exchange can be traced back to the earliest forms of bartering. A lot of philosophers and economists have examined the topic, from Aristotle and his concept of justice to Karl Marx's attack on capitalism. The modern concept of business ethics dates in the 1970s back to the rise of anti big-business protest groups in the United States. The business ethics gradually became an academic field in its own right, with both philosophical and empirical branches. Thanks to government legislation, ethics have been incorporated into businesses. Reflected today in corporate social responsibility strategies and codes of conduct. Business ethics is now not only a firmly established academic field, it is something companies realize they need to manage and internalize (De George, 2007).

Turning now to comprehensively define business ethics, it here treats it primarily as a form of academic enquiry (Marcoux, 2008) and just one sub-field of applied ethics. For people who are engaged in business, ethics might be their own awareness that the conduct of business dealings is to be seen as being right or wrong, or indeed, self-appraisal of their dealings, invoking Adam Smith's impartial spectator (Fleischacker, 2015).

The practice of business ethics De George (2012) defines as the long tradition of applying ethical norms to business, just as it has been applied to other areas of personal life and social life. I also find it useful to refer 
in this context to the definition of business ethics offered by Crane and Matten (2016) who indicate activities and decisions where issues of right (good) and wrong are addressed.

In the essence, business ethics is the application of ethical values to business behavior. Business ethics is relevant both to the conduct of the organization and to the conduct of individuals and as a whole. It applies to all aspects of business conduct, from strategies and how companies treat their suppliers and employees, sales techniques and accounting practices. Ethics goes beyond the legal requirements and regulations for a company and is, for this reason, about behavior guided by values and discretionary decisions.

\section{History of business ethics}

Ethics has existed in religion and philosophy for thousands of years and has been applied to business activities in the same way ethical values and norms have been applied to everyday life. Fair treatment and justice have been a part of our social existence since the beginning of civilization. Aristotle (2000) provides the first recorded definition of justice and fair treatment of all parties in a transaction (De George, 2007).

Key philosophies that built a foundation for business ethics include Locke's (1689) classic defense of property as a natural right. Smith (1776) often identified as the founder of capitalism created the concept of the 'invisible hand' and wrote about self-interest, however, he went on to explain that with six psychological motives is associated the common good. Each individual has to produce for the common good with values such as promoting happiness and prosperity of mankind, prudence, reason, and sentiment (Smith, 2000).

Other contributors to the foundation of business ethics include Mill (1863), Hegel (1820) and Kant (1899). These philosophers wrote on economic fairness, especially on distributive justice (De George, 2007).

Most likely the philosophy that had the most impact on understanding the macro/normative area of business ethics in the last almost sixty years is the contribution of John Rawls (1971). One perspective is the Rawls (1971) difference principle that the worst off position should be made as well off as possible. It is discussed in this time period since the work of Rawls is linked to earlier philosophical discussions of distributive justice.

The time frame from 1960 to the present is selected to reflect almost sixty years of increasing interest and the rapid change of business ethics. This time period shaped the current managerial view of business ethics. This is seen in global ethics programs of corporations. Besides this time has been a critical period of time with respect to global ethics crises and public policy developments designed to institutionalize business ethics around the world.

Although I will attempt to trace the history since 1960 (Table 1), it is appropriate to start by tracing the origins of business ethics thought over the past 100 years. Business Ethics by Frank Chapman Sharp and Phillip D. Fox (1937) was the first managerial textbook on business ethics.

Table 1. Business ethics timeline

\begin{tabular}{|c|c|c|c|c|}
\hline 1960's & 1970's & 1980's & 1990's & 2000's \\
\hline $\begin{array}{l}\text { Environmental } \\
\text { issues }\end{array}$ & $\begin{array}{l}\text { Employee militancy } \\
\text { (us vs. them) }\end{array}$ & $\begin{array}{l}\text { Bribery and illegal } \\
\text { contracting practices }\end{array}$ & $\begin{array}{l}\text { Unsafe work practices in } \\
\text { third world countries }\end{array}$ & $\begin{array}{ll}\text { Emerging } & \text { technology } \\
\text { issues: } & \text { cybercrime, } \\
\text { privacall } & \end{array}$ \\
\hline $\begin{array}{l}\text { Employer/ } \\
\text { Employee } \\
\text { tensions } \\
\end{array}$ & $\begin{array}{l}\text { Human rights issues } \\
\text { (forced labor, low wages, } \\
\text { work environment) }\end{array}$ & Deceptive advertising & $\begin{array}{l}\begin{array}{l}\text { Increased } \\
\text { liability for } \\
\text { damage }\end{array} \\
\end{array}$ & $\begin{array}{l}\text { Intellectual } \\
\text { theft }\end{array}$ \\
\hline $\begin{array}{lr}\text { Civil } & \text { rights \& } \\
\text { race } & \text { relation } \\
\text { issues } & \\
\end{array}$ & $\begin{array}{llr}\text { Firms start practice of } \\
\text { covering up not } \\
\text { confronting issues }\end{array}$ & $\begin{array}{llr}\begin{array}{l}\text { Financial } \\
\text { (savings } \\
\text { scandals) }\end{array} & \& & \begin{array}{r}\text { fraud } \\
\text { loan }\end{array} \\
\end{array}$ & $\begin{array}{l}\text { Financial mismanagement } \\
\& \text { fraud }\end{array}$ & International corruption \\
\hline $\begin{array}{l}\text { Changing work } \\
\text { ethics }\end{array}$ & $\begin{array}{l}\text { Federal Corrupt Practices } \\
\text { Act passes (1977) }\end{array}$ & $\begin{array}{l}\text { Transparency issues } \\
\text { arise }\end{array}$ & \begin{tabular}{lll}
$\begin{array}{l}\text { Federal } \\
\text { Guidelines }\end{array}$ & \multicolumn{2}{c}{ Sentencing } \\
(1991) & for $\quad$ Org. \\
\end{tabular} & $\begin{array}{l}\text { Sarbannes Oxley Act } \\
(2002)\end{array}$ \\
\hline $\begin{array}{l}\text { Drug } \\
\text { escalated }\end{array}$ & $\begin{array}{l}\text { Compliance \& legal to } \\
\text { values orientation }\end{array}$ & $\begin{array}{l}\text { Defense } \quad \text { Industry } \\
\text { Initiatives (1986) }\end{array}$ & $\begin{array}{l}\text { Global Sullivan Principles } \\
\text { (1999) }\end{array}$ & $\begin{array}{l}\text { UN Convention Against } \\
\text { Corruption (2003) }\end{array}$ \\
\hline
\end{tabular}

Source: Own editing based on https://www.ethics.org/resources/free-toolkit/ethics-timeline/

The table does not discuss the business ethics of the 2010s, so I will say a few words here. Ethical climate is the following in 2010's (https://www.ethics.org/resources/free-toolkit/ethics-timeline):

Increasing distrust and cynicism of corporate America. 
Business Ethics and Leadership, Volume 3, Issue 3, 2019

ISSN (online) - 2520-6311; ISSN (print) - 2520-6761

$>$ Occupy Wall Street and growing frustration over income inequality and pay gaps between C-suite and rank-and-file workers.

Unprecedented level of workplace diversity.

Higher expectations for transparency from companies and corporate leaders.

Millennial, largest work cohort in history, are savvy about and connected to technology and social networks; less tied to particular employee or career paths; more comfortable with diversity and with ethical ambiguities.

Main ethics and compliance issues are in 2010's based on Ethics Resource Center (2018):

Appropriate use of big data.

Best strategies for hiring and retaining talented employees in an increasingly fluid labor market.

Extent to which business should be responsible for environmental sustainability.

Facilitating productive relationships in multigenerational workplaces.

Identifying common standards and values in increasingly diverse workplaces.

Responsible use of technology and social media in the workplace.

Responsibility to shareholders and responsibility to larger society.

Social media and networking as agents of positive change and new areas of vulnerability.

Tension between increasing transparency and loss of privacy.

Ethics and compliance program developments like:

- OECD issues Good Practices Guidance for anti-bribery compliance programs.

- Passage of Dodd-Frank Wall Street Reform and Consumer Protection Act.

Figure 1. shows the frequency of appearance of business ethics in the Google Books' database in chronological order between 1900 and 2008. The use of the business ethics shows an exponential trend over the last 30 years, represented by a value of 0.9666 for $\mathrm{R} 2$.

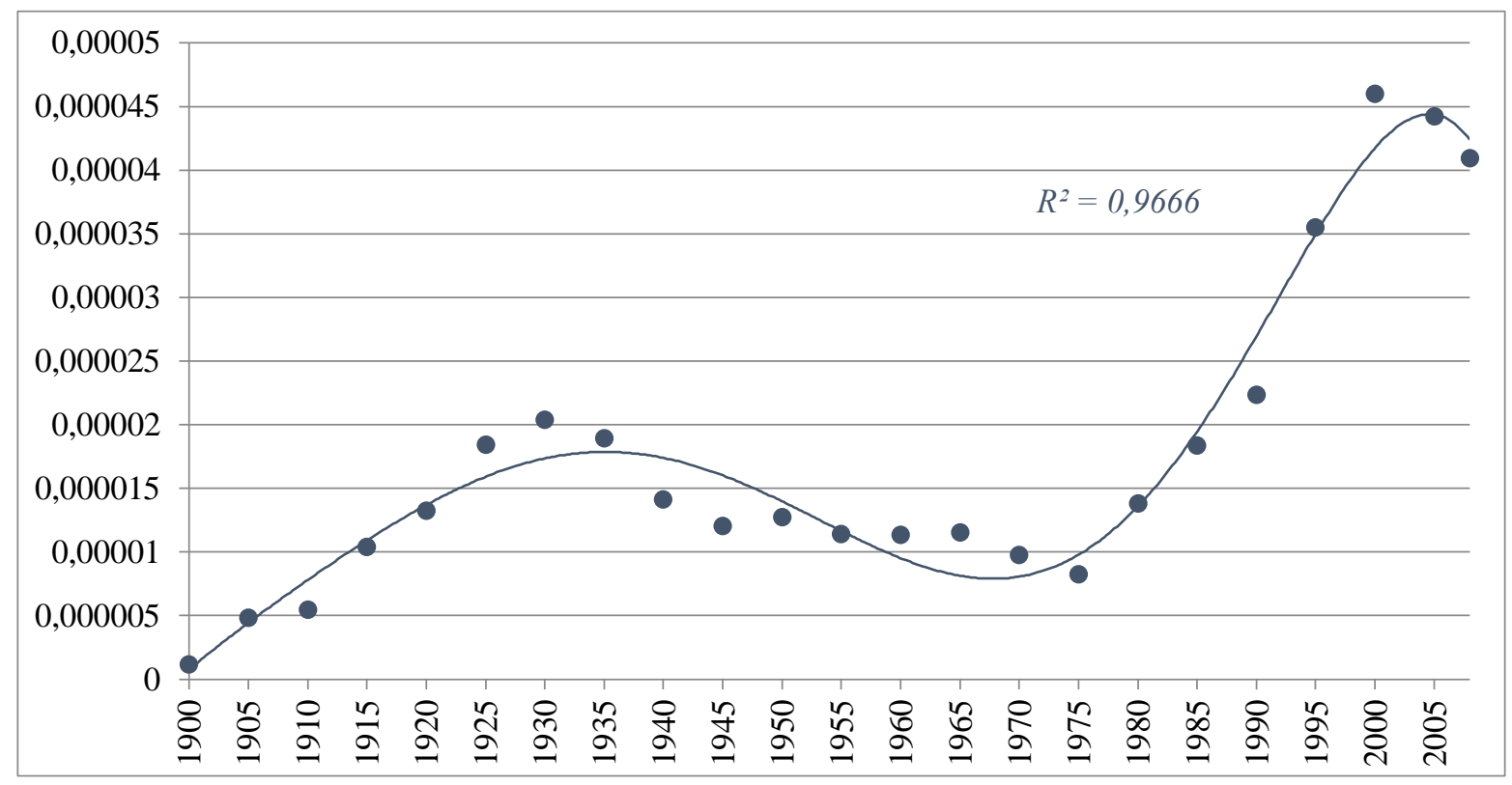

Figure 1. Frequency of appearance of business ethics in the Google Books` database

Source: Own editing based on Google Books Ngram Viewer's data

From 1900 to 1930 the frequency of appearance of business ethics in the Google Books` database has been growing continuously. Pope Pius XI wrote in 1931 Quadragesimo Anno, which morally attacked both laissez-faire capitalism and Soviet socialism. Niebuhr (1932) was perhaps the most influential protestant 
figure whose trenchant critique of social injustice in Moral Man and Immoral Society became the basis for schools of theology and courses in seminaries. After the 1930's the frequency has been decreasing gradually, then stagnated. From the second half of the 1970's, I can see another growth. In the 1990's and at present the frequency growth was very significant. The Parliament of the World's Religions adopted in 1993 a Declaration of a Global Ethic. In the 2000's the frequency has been decreasing gradually.

\section{Elements and principles of business ethics}

Elements of business ethics are (https://businessjargons.com/business-ethics.html):

Formal code of conduct: Those organizations which undertake to inculcate ethical conduct in their business processes establish and implement a code of conduct, for their members and employees. These codes are a statement of organizational values.

- Ethics committee: Many organizations are creating an ethics committee, which is especially dedicated to maintaining ethics in the organization. Such committees raise ethical concerns, develop and modernize the code of conduct, and settle ethical dilemmas.

$>$ Ethical communication: The development of an effective ethical communication system is another major component, which has a great role to play in making the ethics programme successful. It tends to educate employees regarding the ethical standards and norms of the organization.

Ethics office: Next is to create an ethics office, whose work is to communicate and enact policies among various members of the organization.

Disciplinary system: Due to the rapid and serious handling of ethical violations, a disciplinary system needs to be established.

D Ethics training programme: An important aspect is the ethics training programme, in which the employees of the organization undergo training in the framework which defines the ethical norms of the company.

Monitoring: An ethical programme is successful only when an effective monitoring committee is created which looks after various processes and controls deviations.

There are vital ethical principles that should apply to your business in just about any situation. The principles of business ethics are generally as follows (Figure 2) according to Gerald (2018). However, there is a much broader and more diverse set of principles in the literature.

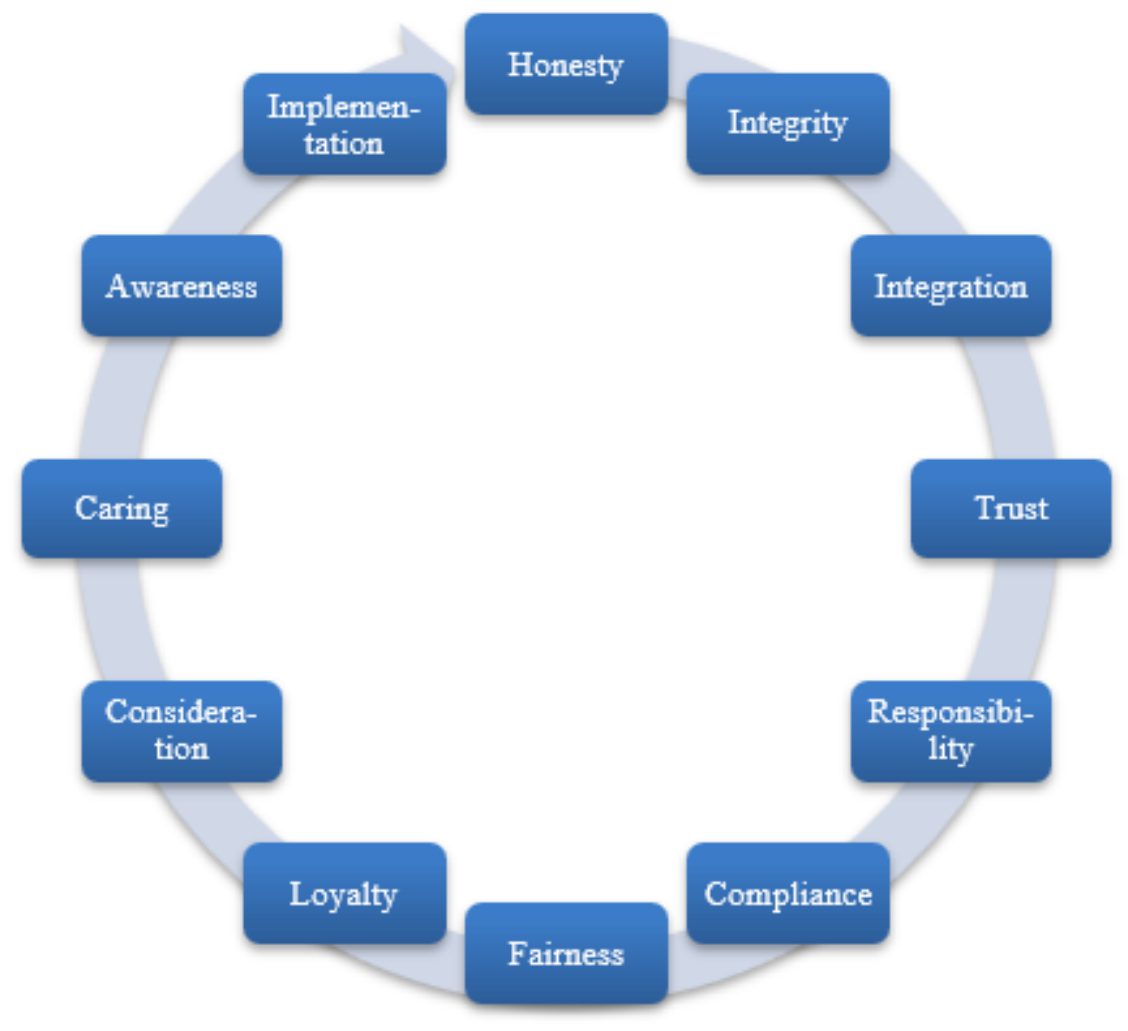

Figure 2. Principles of business ethics 
ISSN (online) - 2520-6311; ISSN (print) - 2520-6761

$>$ Honesty: They say that claims honesty is the best policy and that's true the business world also. Full sincerely as a company value is an integral part of running an ethical company. Without a focus on honesty, a company can mislead consumers and business partners alike. Many of the major scandals in the business world come from a lack of honesty.

> Integrity: It means that you'll draw a firm line between right (good) actions and those that are morally wrong (bad). Executives and others within the company should be free to show their integrity. The company as a whole should avoid crossing the line you've established between right and wrong. Too often people see companies abandon their integrity in favor of easy profits.

$>$ Integration: In the business world the ethics cannot stand alone. It has to integrate ethical practices into the company at every level to truly be an ethical company. By integrating principles of ethics into the company's policies and business practices, it will create an ethical company from the inside out.

Trustworthiness: This is an ethical practice that expresses it to how your company handles itself over time. Trustworthiness is built by showing that the company will act ethically in good times and bad, over and over again. A trustworthy company will build a strong reputation over time. It may very well enjoy more business than it would have by taking the quick and easy way out when times are tough.

$>$ Responsibility: A company has an ethical obligation to its customers, its partners and its employees. If this obligation and responsibility is ignored, that business will often take unethical measures or avoid unfavorable situations or shortcuts to maximize profits. To really run an ethical company, it has to recognize the responsibilities that the company has to others. Once realized, it then has to take steps to ensure that your company lives up to those responsibilities and acts ethically toward all involved.

Compliance: Compliance with ethical laws and standards seems like it should be easy for a business to achieve but think of how often it has seen scandals break out. There's more to compliance than just following the law, however. Compliance also means making sure that the company follows its code of ethics and ethical standards that are not codified into law.

$>$ Fairness: In some cases, it's difficult to be fair in business. A company has to act with fairness, both internally and toward customers or business partners. The company has to treat employees fairly, providing opportunities for advancement and perks to all who qualify. The company has to treat other companies fairly, avoiding the temptation to give one company or another an unfair advantage in your dealings in exchange for some hidden perk. The company has to treat customers fairly, making sure that you don't build unreasonable expectations through marketing.

$>$ Loyalty: This is most often used to employees being faithful and loyal to the company. It also applies to the company being loyal to its employees and subsidiary. The company shouldn't pursue profits with no regard to how it might affect business partners, employees or suppliers. It shouldn't lay off workers or cut jobs without exploring other cost-saving options first. If the company does have to take adverse actions, does it best to provide some form of severance or other benefits to try and maintain the relationships the company has created.

$>$ Consideration: If the business finds yourself facing an ethical dilemma while running your business, ask questions that in this situation, what is an example of ethical behavior? Putting this sort of focus on the situation will help it approach it without taking unethical actions. Weigh your decisions against the possible negative outcomes of acting unethically. Consider how your actions will affect both the company's reputation and those it interacts with.

Caring: Caring about others is indispensable ethically. Caring includes caring about the well-being of customers as well as that of employees or business partners. The practices are unethical if practices potentially harm workers. If a product is potentially harming customers, but a decision is made to keep it on the market because of its profit potential, that decision puts profits over the well-being of customers and is unethical.

$>$ Awareness: The business take may have aftermaths. Some of the aftermaths may have a positive or even negative. It's major that the business remains aware of this since without this consciousness it becomes easier to lapse into unethical behavior. A lack of consciousness often leads to a lack of caring, especially if that lack of consciousness puts consumers or workers at risk. If you assume that your behaviors only affect the business and have no greater impact on the community or world around it, it indicates it may take increasingly unethical steps over time. 
Implementation: Discussions about the ethical positions of the company do not necessarily result in ethical actions without implementation. For a company to really be ethical, it's essential that it creates a code of ethical conduct and implement the code into its business strategy.

\section{Methodology and Research Methods}

The main goal of this study is to examine the role of business ethics and the principles of business ethics in Google Trends from 2004 to the present worldwide by country in the fields of science, business and industry and over and above in law and government. The search and query time was 11.08.2019. Another goal of my study is to look at how often the term business ethics appears in books, with the help of Google Books Ngram Viewer, over a period of time between 1900 and 2009.

Google Trends (Figure 3) is a search trends feature. It shows how frequently a given search term is entered over a given period of time into Google's search engine relative to the site's total search volume. Google Trends can be used to discover event-triggered spikes in keyword search volume in addition to comparative keyword research. So, Google Trends provides keyword-related data. It gives search volume index and geographical information about search engine users.

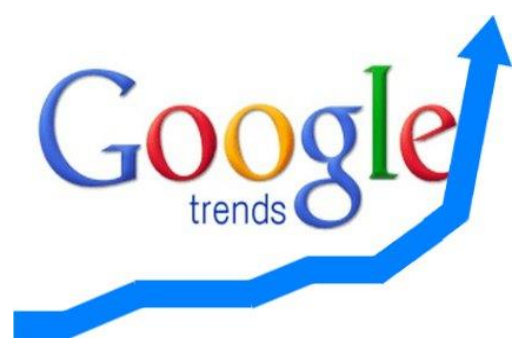

Source: Google Trends

Figure 3. Google Trends icon

Google Trends shows related search terms and how search interest varies by country. Man can also enter a search term into the search box at the top of the tool to see how search volume has varied for that both over time and in different geographical locations. People can change the geographical location, category, time frame or industry, and type of search (web, news, shopping, or YouTube) for more accurate and detailed (https://www.wordstream.com/google-trends).

The Google Books Ngram Viewer (Figure 4) is an online search platform for Google's text. Searches can be conducted for the years between 1800 and 2008 in Google's text in different languages. When entering phrases into the Google Books Ngram Viewer, it displays a graph showing how those phrases have occurred in a corpus of books over the selected years (https://books.google.com/ngrams/info).

\section{Google Books Ngram Viewer}

Source: https://books.google.com/ngrams

Figure 4. Google Books Ngram Viewer icon

\section{Results}

In the following, I summarize the frequency of the investigated term that is business ethics in Google searches with the help of Google Trends. I searched in Google Trends worldwide interest by country in the science, in the business and industry and over and above in the law and government category.

\section{Top year and bottom year of interest in business ethics}

Table 2. summarizes the worldwide interest frequency of the investigated term in Google Trends. The numbers represent the search interest relative to the highest point in the graph for the country and time period. A value of 100 is the highest popularity of the term; a value of 50 indicates that the term is half as popular. 0 means that there is not enough data for the expression. 
Table 2. Top year and bottom year of interest

\begin{tabular}{|l|c|c|}
\hline \multicolumn{1}{|c|}{ Interest/Category } & Bottom year & Top year \\
\hline all & $07.2017: 16$ & $03.2004: 100$ \\
\hline business and industry & $07.2017: 12$ & $03.2004: 100$ \\
\hline science & $08.2005: 0$ & $07.2004: 100$ \\
\hline law and government & $06.2019: 7$ & $04.2004: 100$ \\
\hline
\end{tabular}

Source: Own editing based on Google Trends' data

The top year of the interest frequency of business ethics was 2004 in all 4 investigated categories. The bottom year of the interest frequency was 2017 in all and the business/industry category. 2005 was the bottom year in the science category and 2019 in the law/government category.

\section{Interest frequency of business ethics}

In the following, I present the search frequency over time for business ethics on average by category and by country in Google Trends.

Figure 5. shows the interest frequency of business ethics in Google Trends from 2004 to the present by category.

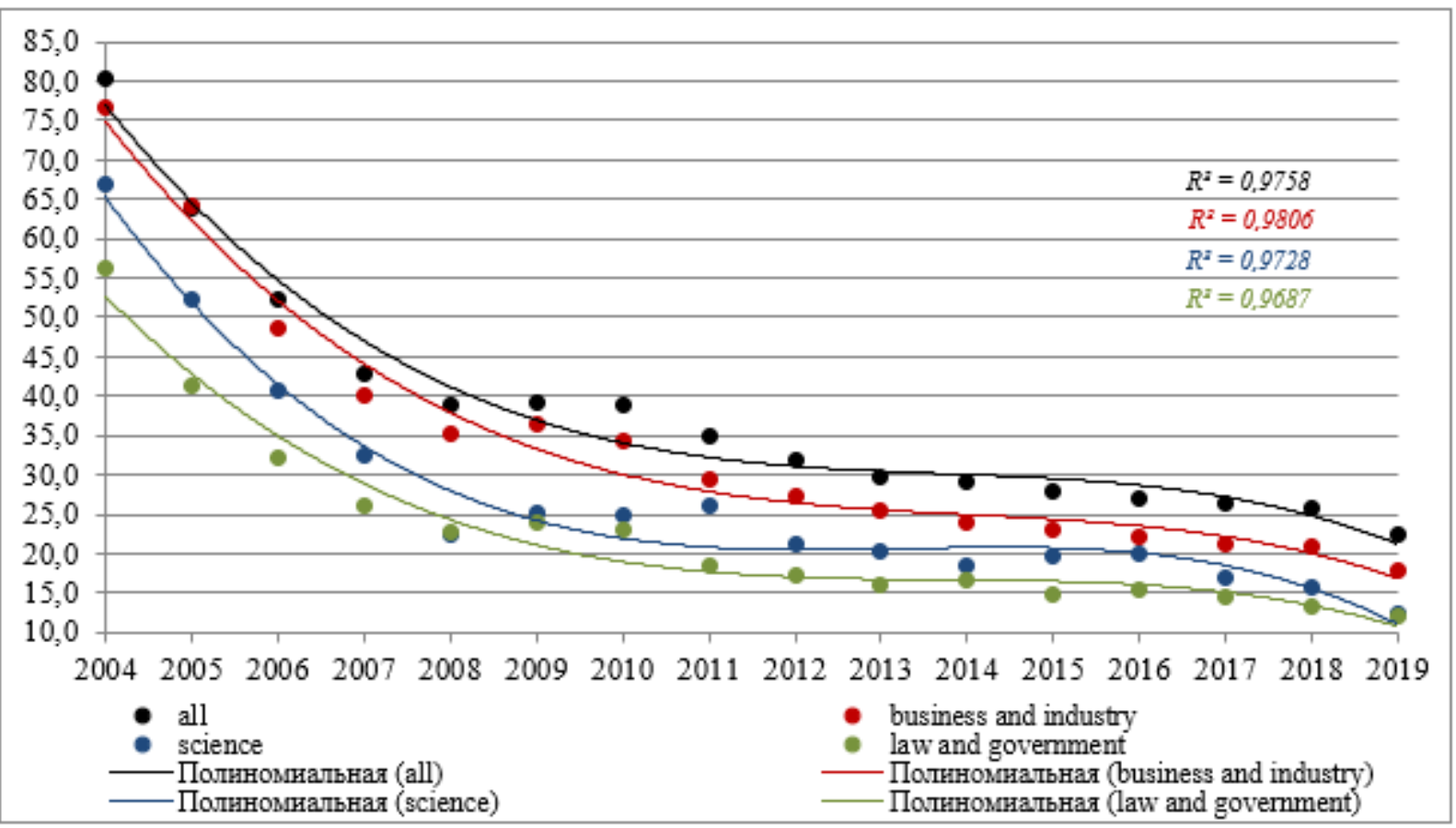

Figure 5. Interest over time on average

Source: Own editing based on Google Trends' data

Figure 5. shows the highest interest frequency of business ethics in all categories, after that in the business and industry category, then in the science category, finally in the law and government category. On average the highest interest frequency was in 2004 in all examined categories. A third-degree polynomial downward trend can be fitted to each time series. In all cases the value of $R^{2}$ is very good.

Figure 6. exhibits the interest frequency of business ethics in Google Trends by top country in all categories. It shows where the term was most popular during the given time period. Values represented by various shades of blue and grey are on a scale of 0 to 100, where 100 (dark blue) is the place with the highest number of searches relative to the total number of searches; a value of 50 (light blue) indicates the place where the popularity is half. 0 (light grey) indicates the place where there is not enough data for the expression. Note: A higher value represents a higher proportion of all queries than a higher absolute number of queries. For example, a tiny country where $80 \%$ of queries relate to bananas will score twice as big as a huge country where only $40 \%$ of queries apply to bananas. 


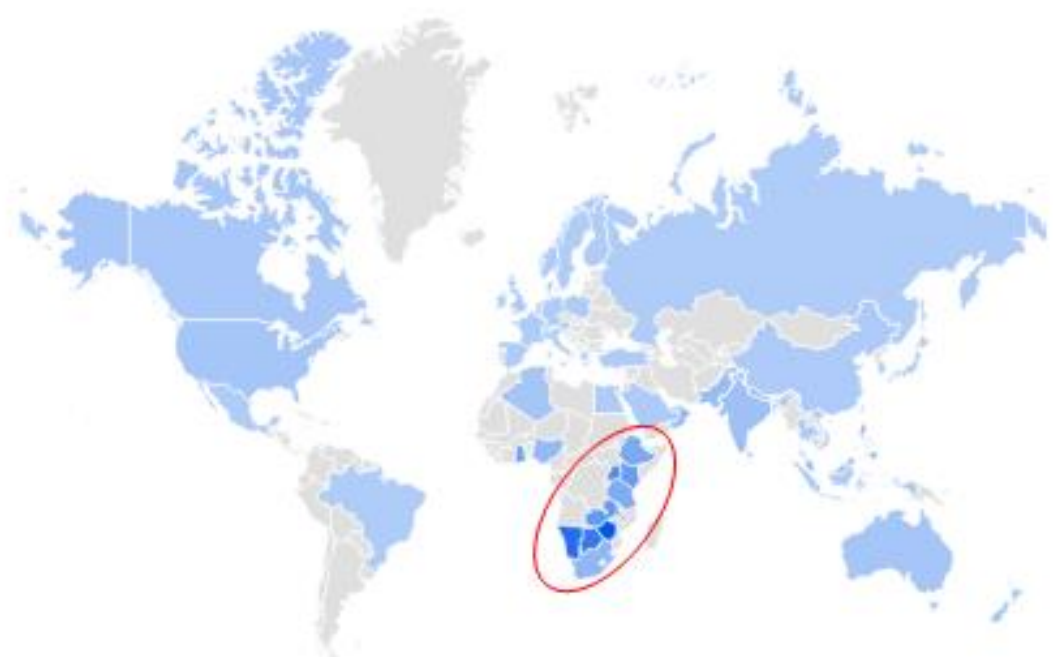

Figure 6. Interest by country in all categories

The map depicted in Figure 6. shows that most people searched in Zimbabwe (100), in Namibia (81), in Botswana (70), in Malawi (64) and in Uganda (57) for the term business ethics. Interestingly, these countries are all located on the African continent. What could be the reason that this term is so popular there? There is a scanty piece of information regarding business activities of private individuals in Eastern and Southern Africa. The official records show that there is still a limited business activity undertaken by private individuals in the region. The wind of change in the late 1980s necessitated the national states, institutions and private individuals to seek for a closer co-operation in business and other activities. Ethical issues have been on top of the agenda of every nation because of the perceived development and improvement of business enterprises. Each national government in the region tries to accept such a challenge and to design measures to enhance regional and national ethics compatibility in business. Many institutions and various stakeholders in Eastern and Southern Africa are encouraged to participate and co-operate for the betterment of the region (Milanzi, 1997). For several years now Transparency International has placed some African countries high on its list of most corrupt countries of the world. The conclusion one draws from this assessment is that either African culture has no regard or concern for ethics, or that there has been a gradual loss of the concept of the ethical and the moral in contemporary African society. Equally problematic is the teaching and promotion of business ethics in organizations. Western philosophical theories and systems alone have not succeeded in providing access to ethical life of people in modern Africa (Gichure, 2006). These may be the reasons why people searched Google for business ethics very frequently in these countries.

Figure 7. shows the interest frequency of business ethics in Google Trends by top country in the business and industry category.

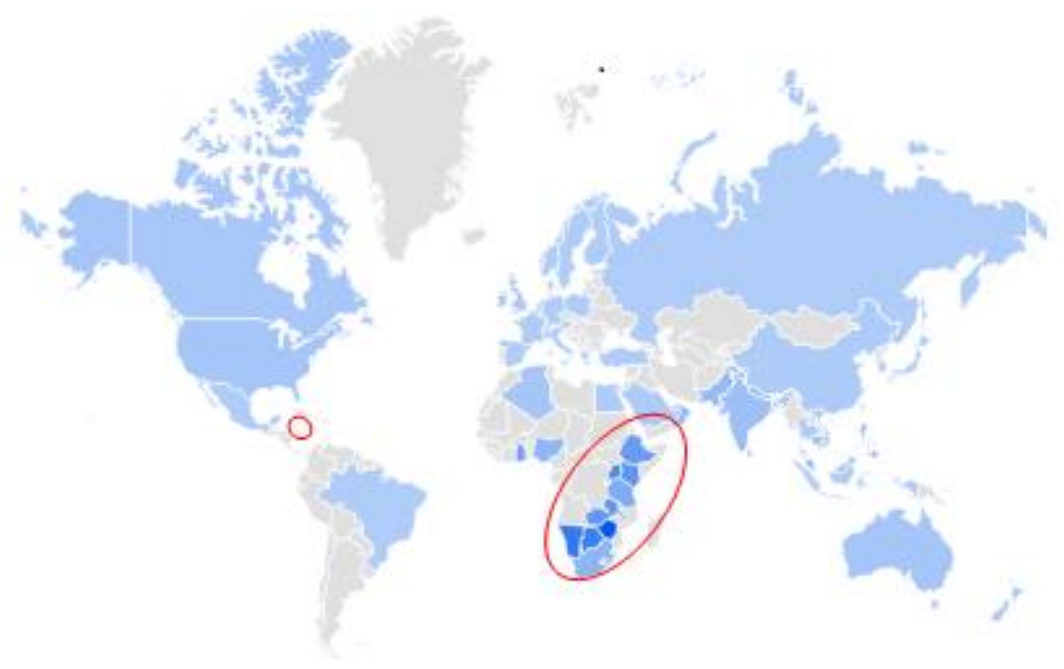


Business Ethics and Leadership, Volume 3, Issue 3, 2019

ISSN (online) - 2520-6311; ISSN (print) - 2520-6761

The map shows that most people searched in Zimbabwe (100), in Namibia (72), in Malawi (68), in Botswana (66) and in Jamaica (59) for the term business ethics. Again, most of these countries are located on the African continent and on the Central American continent. What could be the reason this term is so popular also in Jamaica? Jamaican businesses operating in certain commercial areas in the country are faced with one such dilemma which appears to derive from the unique characteristics of their social and economic space. They are faced with the challenge of maintaining profitability and functioning as responsible corporate citizens while coping with the extortion carried out by members of the informal militias of garrison communities acting on behalf of the dons who run these communities (Charles, 2007). Speaking at a panel discussion held at the Old Hope Road campus of the University of Technology on February 23 in 2012, Sharon Ffolkes Abrahams, Minister of State for Industry, Investment and Commerce said that the government is committed to addressing the issue of ethics in business and this move is critical in promoting good corporate governance practices among registered companies. Jamaica has a serious problem with corruption therefore business ethics must be addressed in order to improve the country's business environment and to attract new investment, including foreign direct investment (Linton, 2012).

Figure 8. shows the interest frequency of business ethics in Google Trends by top country in the science category.

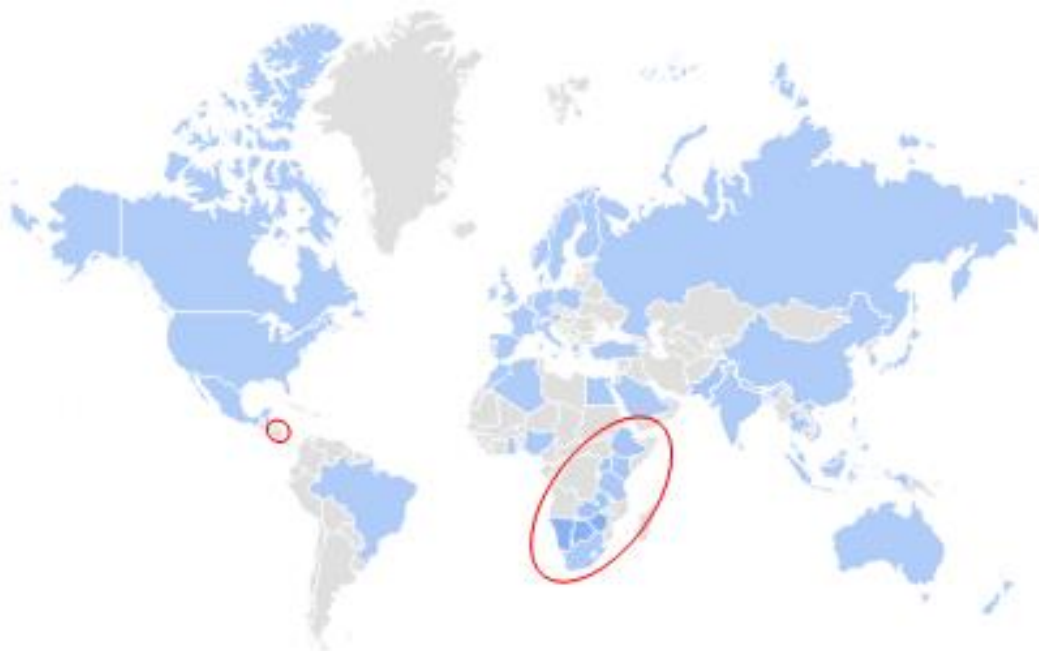

Source: Google Trends

Figure 8. Interest by country in the science category

The map shows that most people searched in Belize (100), in Zimbabwe (23), in Botswana (22), in Namibia (22) and in Malawi (13) for the term business ethics. When analyzing the motivation for this we find that Belize is in a similar position to Jamaica.

Figure 9. shows the interest frequency of business ethics in Google Trends by top country in the law and government category.

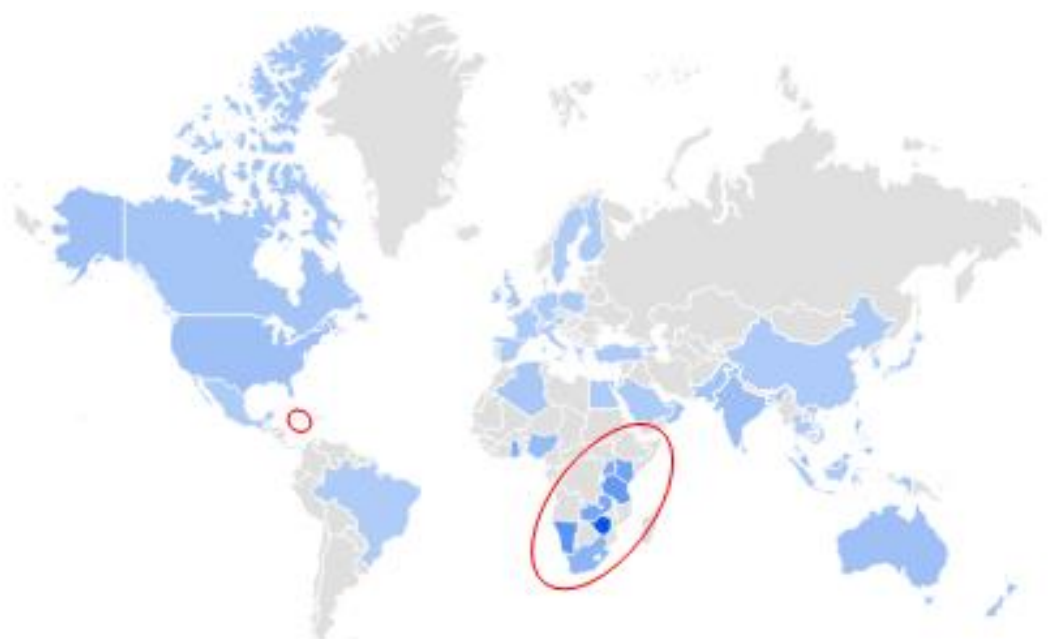


The map shows that most people searched in Zimbabwe (100), in Namibia (48), in Tanzania (43), in Jamaica (40) and in Kenya (34) for the term business ethics.

\section{Interest frequency of the principles of business ethics}

In the following, I summarize the frequency of the principles of business ethics in Google searches with the help of Google Trends. I searched in Google Trends worldwide interest by country in all and in the business category.

I present the search frequency over time for business ethics on average by all category and by country in Google Trends. Figure 10. shows the interest frequency of principles of business ethics in Google Trends from 2004 to the present by all category. I divided the 12 principles into 3 groups. Honesty, consideration and integration, the research for these principles stagnated. The research for caring, responsibility, integrity, trustworthiness, fairness showed a decrease. The research of the compliance principle has increased.

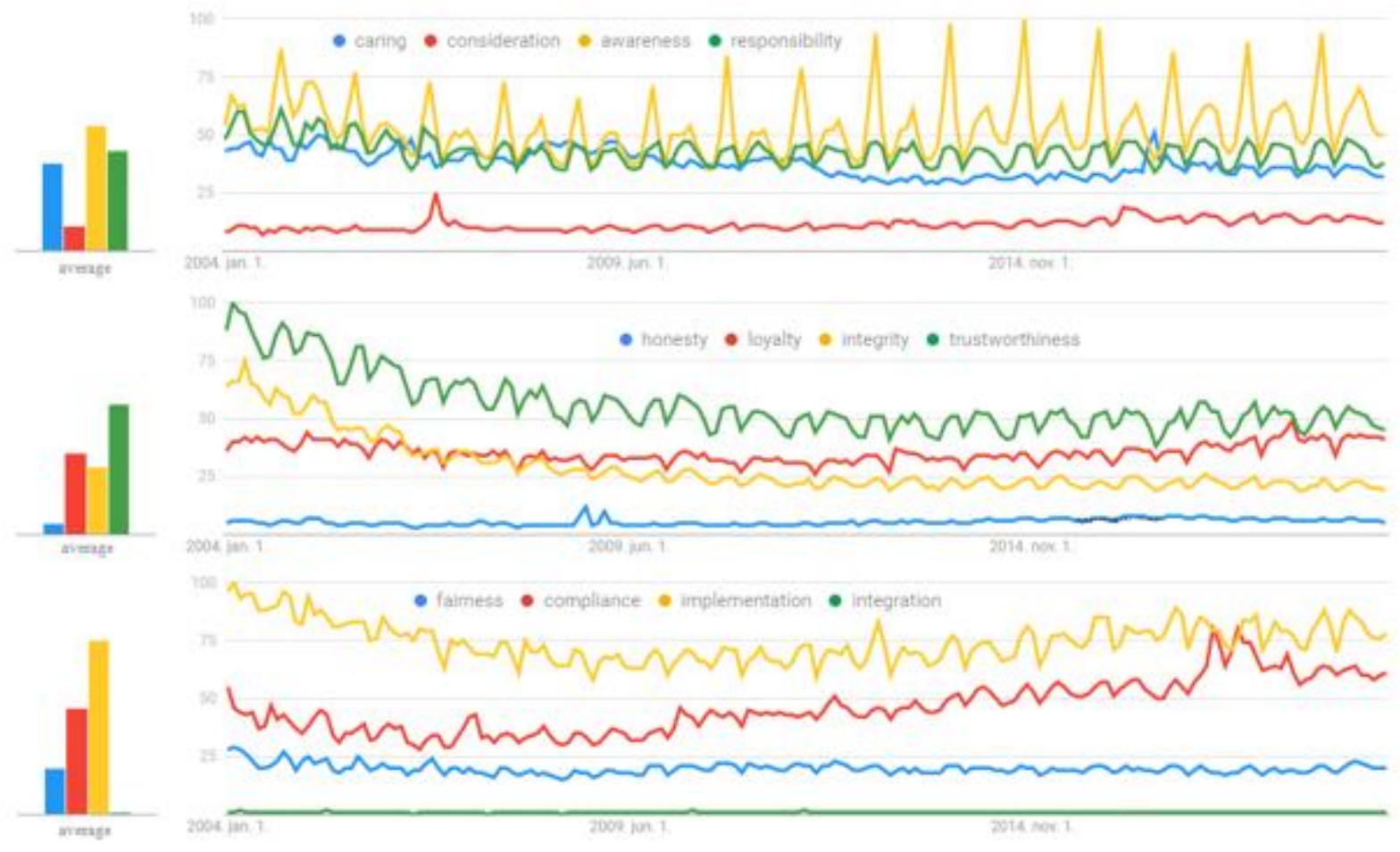

Figure 10. Interest over time on average in the all category

Source: Own editing based on Google Trends' data

Figure 11. shows the interest frequency of principles of business ethics in Google Trends from 2004 to the present by business and industry category. I divided the 12 principles into 3 groups. Consideration, honesty, fairness, integration and awareness, the research for these principles stagnated. The research for caring, responsibility, integrity, trustworthiness, loyalty, compliance and implementation principles showed a decrease. 


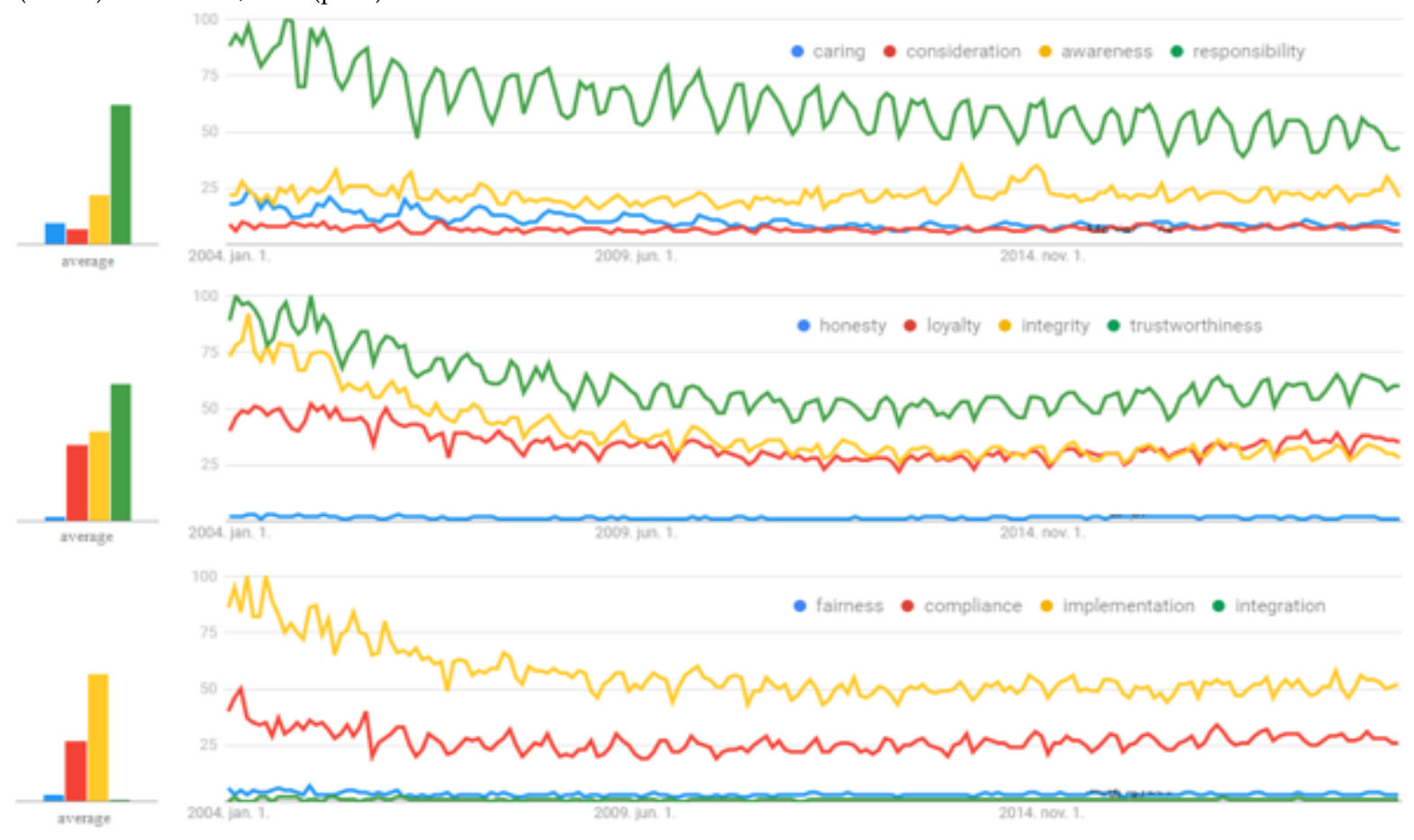

Figure 11. Interest over time on average in the business and industry category Source: Own editing based on Google Trends' data

Table 3. summarizes the worldwide interest frequency of the principles of business ethics in Google Trends. The numbers represent the search interest relative to the highest point in the graph for the country and time period. A value of 100 is the highest popularity of the term; a value of 50 indicates that the term is half as popular. 0 means that there is not enough data for the expression.

Table 3. Top and bottom year of interest and interest by country in the all and business/industry category

\begin{tabular}{|c|c|c|c|c|}
\hline $\begin{array}{c}\text { Principles of } \\
\text { business ethics }\end{array}$ & $\begin{array}{l}\text { Category/ } \\
\text { Interest }\end{array}$ & $\begin{array}{c}\text { Bottom } \\
\text { year }\end{array}$ & Top year & Top 5 country \\
\hline \multirow{2}{*}{ honesty } & all & 08.2008: 50 & 01.2004: 100 & Philippines, Nigeria, Jamaica, Trinidad \& Tobago, Ghana \\
\hline & business/industry & 01.2007: 22 & 05.2004: 100 & Nigeria, Philippines, Ethiopia, Uganda, Kenya \\
\hline \multirow{2}{*}{ awareness } & all & 12.2008: 36 & 10.2014: 100 & Jamaica, Philippines, South Africa, USA, India \\
\hline & business/industry & 12.2011: 42 & 10.2013: 100 & Zimbabwe, India, Singapore, Philippines, Kenya \\
\hline \multirow{2}{*}{ caring } & all & 12.2012: 54 & 07.2016: 100 & Jamaica, Ghana, Malaysia, USA, South Africa \\
\hline & business/industry & 01.2013: 28 & 04.2004: 100 & Jamaica, Australia, Malaysia, UK, USA \\
\hline \multirow{2}{*}{ compliance } & all & 12.2011: 53 & 05.2018: 100 & Saint Helena, Hong Kong, Singapore, Australia, South Africa \\
\hline & business/industry & 12.2012: 40 & 02.2005: 100 & Saint Helena, Singapore, South Africa, Hong Kong, Luxemburg \\
\hline \multirow{2}{*}{ consideration } & all & 08.2004: 27 & 11.2006: 100 & Zambia, Ethiopia, Tanzania, Ghana, Zimbabwe \\
\hline & business/industry & 08.2006: 30 & 03.2014: 100 & Botswana, Ethiopia, Zimbabwe, Namibia, Tanzania \\
\hline \multirow{2}{*}{ fairness } & all & 08.2006: 27 & 11.2008: 100 & Sri Lanka, India, Pakistan, Mauritius, Ghana \\
\hline & business/industry & 02.2004: 17 & 08.2004: 100 & Philippines, Zimbabwe, Sri Lanka, Mauritius, Pakistan \\
\hline \multirow{2}{*}{ implementation } & all & 12.2012: 26 & 03.2004: 100 & Ethiopia, Zimbabwe, Kenya, Uganda, Zambia \\
\hline & business/industry & 12.2012: 29 & 04.2004: 100 & Botswana, Zimbabwe, Ethiopia, Kenya, Uganda \\
\hline \multirow{2}{*}{ integrity } & all & 12.2008: 56 & 02.2004: 100 & Jamaica, Trinidad \& Tobago, Kenya, Ghana, Nigeria \\
\hline & business/industry & 12.2012: 39 & 04.2004: 100 & Uganda, Kenya, Trinidad \& Tobago, Jamaica, Ghana \\
\hline \multirow{2}{*}{ integration } & all & 07.2016: 39 & 02.2004: 100 & Ethiopia, Jamaica, Singapore, Saint Helena, Ghana \\
\hline & business/industry & 12.2012: 42 & 02.2004: 100 & Ethiopia, Saint Helena, Singapore, Kenya, Ghana \\
\hline \multirow{2}{*}{ loyalty } & all & 08.2006: 33 & 08.2017: 100 & Ghana, Jamaica, Trinidad \& Tobago, South Africa, Philippines \\
\hline & business/industry & 07.2009: 37 & 03.2004: 100 & Zimbabwe, Mauritius, Singapore, Kenya, Ghana \\
\hline \multirow{2}{*}{ responsibility } & all & 07.2015: 58 & 11.2004: 100 & Zimbabwe, Ethiopia, Ghana, Jamaica, Nigeria \\
\hline & business/industry & 07.2017: 39 & 04.2004: 100 & Zimbabwe, Botswana, Ghana, Kenya, Ethiopia \\
\hline \multirow{2}{*}{ trustworthiness } & all & 08.2006: 19 & 04.2010: 100 & $\begin{array}{l}\text { Trinidad \& Tobago, South Africa, Philippines, Nigeria, } \\
\text { Singapore }\end{array}$ \\
\hline & business/industry & 02.2004: 0 & 03.2005: 100 & $\begin{array}{l}\text { South Africa, Philippines, Trinidad and Tobago, Kenya, } \\
\text { Singapore }\end{array}$ \\
\hline
\end{tabular}

Source: Own editing based on Google Trends' data

Generally, the top year of the interest frequency of the principles of business ethics was 2004 in all 2 investigated categories, just like the term of business ethics. The interest frequency in each of the examined 
principles was most significant in the countries of South Africa (Zambia, Botswana, Zimbabwe, South Africa), West (Nigeria, Ghana) and Central Eastern Africa (Ethiopia, Uganda, Kenya, Tanzania). The interest of 8 of 12 principles was significant from the Caribbean (Jamaica and Trinidad \& Tobago). The frequency of awareness and caring was remarkable in the USA, in addition to the principle of caring the compliance in Australia. From European countries in UK was the caring, in Luxemburg was the compliance. The islands belonging to Europe from Mauritius and Saint Helena the interest was significant. In the countries of Asian (India, Hong Kong and Pakistan) with islands such as Philippines, Sri Lanka, Singapore and Malaysia the interest of the principles of awareness, caring, compliance, fairness, integration and trustworthiness were significant.

\section{Conclusions, Discussions and Recommendations}

Since the early 1960's and 1970's business ethics has come in vogue. Definition of business ethics connotes the form of applied ethics, which studies morals, ethical principles and problems in the business environment. It is meaning the integration of general morals and ethical norms to business. This is applying to all types of business. In another sense, it implies the right (good) or wrong behavior, in pursuing business, determined on the basis of expected behavior approved by the society.

The elements of business ethics are formal code of conduct, ethics committee, ethical communication, ethics office, disciplinary system, ethics training programme, and monitoring.

The principles of business ethics are awareness, caring, compliance, consideration, fairness, honesty, implementation, integrity, integration, loyalty, responsibility, and trustworthiness.

Ethics has existed in religion and philosophy for thousands of years and has been applied to business activities in the same way ethical values and norms have been applied to everyday life. Fair treatment and justice have been a part of our social existence since the beginning of civilization. Key philosophies that built a foundation for business ethics include Aristotle's, Locke' (1689), Smith's (1776), Mill's (1863), Hegel's (1820), Kant's (1899), Sharp's - Fox's (1937) and Eawl's (1971).

In Google Books use of the term business ethics phrase show an exponential trend. XI. Pope Pius wrote the book Quadragesimo Anno in 1931, which was a milestone next to Niebuhr's critique of capitalism in the Moral Man and Immoral Society in 1932. In the 1990's and at present this growth was very significant. In 1993 the Parliament of the World's Religions adopted a Declaration of a Global Ethic.

Based on the results of Google Trends this study shows that in East Central (Uganda, Kenya and Tanzania) and South African (Zimbabwe, Namibia, Botswana, Malawi and Zambia) and in Central American or Caribbean (Jamaica and Belize) due to corruption and the specific situation and position of businesses the business ethics need serious improvement. The highest interest frequency of business ethics is when looking at all categories together, after that in the business and industry category, then in the science category, finally in the law and government category. On average the highest interest frequency was in 2004 in all examined categories. A third-degree polynomial downward trend can be fitted to each time series.

The interest frequency of the principles of business ethics was most significant in South and Central East Africa, in South and Southeast Asia, over and above in the Caribbean. Out of the 12 keywords examined alone the research of the compliance principle has increased.

\section{References}

1. Aristotle (2000). Nicomachean Ethics. Cambridge Texts in the History of Philosophy. Ed. Crisp, R. Cambridge University Press, Cambridge.

2. Beauchamp, T. L., \& Bowie, N. E. (1997). Ethical Theory and Business. Prentice Hall, New Jersey.

3. Business Jargons (2019). Business Ethics. Available at: https://businessjargons.com/business-ethics.html Accessed 11 August 2019.

4. Gerald, J. (2018). 12 Principles of Ethics. Bizfluent Management. Available at: https://bizfluent.com/info7746524-12-principles-ethics.html. Accessed 11 August 2019.

5. Charles, C. (2007). Business Ethics in Jamaica and the Problem of Extortion by Counter Societies. Ethical Perspectives for Caribbean Business. Eds. Cowell, N. E., Campbell, A., Chen, G. \& Moore, S., Arawak Publications, 2007. Available at: https://ssrn.com/abstract=2372120. Accessed 11 August 2019.

6. Cheney, G., Lair, D. J., Ritz, D., \& Kendall, B. E. (2010). Just a Job? Communication, Ethics, and Professional Life. Oxford University Press. New York. 
Business Ethics and Leadership, Volume 3, Issue 3, 2019

ISSN (online) - 2520-6311; ISSN (print) - 2520-6761

7. Cohen, D., \& Technical Information Service (2008). Business ethics. Topic Gateway Series No. 46. The Chartered Institute of Management Accountants, London.

8. Crane, A., \& Matten, D. (2016). Business Ethics: Managing corporate citizenship and sustainability in the age of globalization. $4^{\text {th }}$ edition, Oxford University Press, New York.

9. De George, R. T. (1982). Business Ethics. $5^{\text {th }}$ edition, Macmillan, New York.

10.De George, R. T. (2007). A History of Business Ethics, Markkula Center for Applied Ethics, www.scu.edu/ethics/practicing/focusares/business/conference/presentations/business. Accessed 10 August 2019.

11.De Geroge, R. T. (2012). A history of business ethics. In BBVA (Ed.) Values and ethics for the $21^{\text {st }}$ century, 337-359. BBVA OpenMind Banco Bilbao Vizeaya Argentaria, Bilbao.

12.Donaldson, T., \& Werhane, P. (1999). Ethical Issues in Business: A Philosophical Approach. Prentice Hall, New Jersey.

13.Ethics \& Compliance Initiative (2018). Business Ethics and Compliance Timeline. Available at: https://www.ethics.org/resources/free-toolkit/ethics-timeline. Accessed 10 August 2019.

14.Ferrell, O. C., Fraedrich, J., \& Ferrell, L. (2008). Business Ethics: Ethical Decision Making and Cases. Houghton Mifflin Company, Boston.

15.Gichure C. W. (2006). Teaching Business Ethics in Africa: What Ethical Orientation? The Case of East and Central Africa. Journal of Business Ethics, 63(1), 39-52.

16.Hegel, G. W. (1820). Elements of the Philosophy of Right. Ed. Wood, A. W., 1991. Cambridge University Press, Cambridge.

17.Kant, I. (1899). Critique of Pure Reason. Colonial Press, New York.

18.Linton, L. (2012). Gov't Committed to Addressing Business Ethics. Jamaica Information Service. Available at: https://jis.gov.jm/govt-committed-to-addressing-business-ethics/. Accessed 11 August 2019.

19.Locke, J. (1689). Second Treatise: An Essay Concerning the True Original, Extent and End of Civil Government. Available at: https://www.earlymoderntexts.com/assets/pdfs/locke1689a.pdf. Accessed 10 August 2019.

20.Milanzi, M. C. (1997). Business Ethics in Eastern and Southern Africa. Journal of Business Ethics, 16(14), 1549-1553.

21.Mill, J. S. (1863). Utilitarianism. Available at: https://www.utilitarianism.com/mill1.htm. Accessed 10 August 2019.

22.Niebuhr, R. (1932). Moral Man and Immoral Society. Scribner's, New York.

23.Pius XI, Pope (1931). Quadragesimo Anno. Available at: http://w2.vatican.va/content/piusxi/en/encyclicals/documents/hf_p-xi_enc_19310515_quadragesimo-anno.html. Accessed 11 August 2019.

24.Rawls, J. (1971). A Theory of Justice. Harvard University Press, Cambridge.

25.Salehi, M., Saeidinia, M., \& Aghaei, M. (2012). Business Ethics. International Journal of Scientific and Research Publications, 2(1), 91-95.

26.Sharp, F. C., \& Fox, P. G. (1937). Business Ethics: Studies in Fair Competition. D. Appleton-Century Company. New York.

27.Smith, A. (1776). An Inquiry into the Nature and Causes of the Wealth of Nations. Available at: https://www.ibiblio.org/ml/libri/s/SmithA_WealthNations_p.pdf. Accessed 10 August 2019.

28.Ugoji, K., Dando, N. \& Moir, L. (2007). Does ethics pay? - revisited. Institute of Business Ethics, London.

29.Your Dictionary (2018). Dictionary definitions: business ethics. Available at: https://www.yourdictionary.com/business-ethics. Accessed 10 August 2019.

30.Velasquez, M. G. (2002). Business Ethics: Concepts and Cases, Prentice Hall. New Jersey.

31.WordStream (2017). Google Trends: What Is Google Trends? Available at: https://www.wordstream.com/google-trends. Accessed 10 August 2019. 